http://dx.doi.org/10.12775/szhf.2014.012

\title{
Czesława Piecuch (red.), Karl Jaspers: Człowiek w epoce przełomu, Wydawnictwo Naukowe Uniwersytetu Pedagogicznego, Kraków 2013, ss. 234
}

Zainteresowanie filozofią Karla Jaspersa przeżywa w ostatnich latach istny renesans. Dowodzą tego liczne publikacje poświecone jego twórczości oraz ukazujące się regularnie dzieła niemieckiego filozofa ${ }^{1}$. Na pierwszym miejscu należałoby tu wymienić znakomitą monografię Czesławy Piecuch. Autorka, która dała się już poznać również jako tłumaczka dzieł Jaspersa², zajmuje się w tej pracy metafizycznymi elementami jego twórczości. Z zupełnie innej perspektywy prowadzi natomiast swe badania Andrzej Kapusta ${ }^{3}$. Ze względu na posiadane wykształcenie ${ }^{4}$ skierował on swe zainteresowanie

${ }^{1} \mathrm{Z}$ ubolewaniem należy odnotować fakt, że wciąż nie doczekaliśmy się polskiego wydania trzech, spośród czterech najważniejszych dzieł Jaspersa, tj. Psychologie der Weltanschauungen (1919), trzytomowej Philosophie (1931), z której dostępne są już po polsku obszerne fragmenty, a także Von der Wahrheit (1945). (Czwartą pracą, którą mam na myśli, jest oczywiście K. Jaspers, Wiara filozoficzna wobec objawienia, tłum. G. Sowinski, Znak, Kraków 1999). Cieszy natomiast wznowienie Jaspersowskiej monografii o Nietzschem, której reedycja dowodzi dużego zaufania czytelników wobec analiz dokonywanych przez niemieckiego filozofa, patrz: K. Jaspers, Nietzsche. Wprowadzenie do rozumienia jego filozofii, tłum. D. Stroińska, Wydawnictwo Oficyna, Łódź 2012. Warto również wspomnieć, że w 2014 roku nakładem Wydawnictwa Naukowego UMK ukaże się monografia Jaspersa poświęcona twórczości Sørena Kierkegaarda.

${ }^{2}$ Por. K. Jaspers, Rozum i egzystencja. Nietzsche i chrześcijaństwo, tłum. Cz. Piecuch, Wydawnictwo PWN, Warszawa 1991; tenże, Szyfry transcendencji, tłum. Cz. Piecuch, Wydawnictwo Comer, Toruń 1995.

${ }^{3}$ Cz. Piecuch, Metafizyka egzystencjalna Karla Jaspersa, TAiWPN Universitas, Kraków 2011; A. Kapusta, Szaleństwo i metoda. Granice rozumienia w filozofii i psychiatrii, Wydawnictwo Uniwersytetu Marii Skłodowskiej-Curie, Lublin 2010.

${ }^{4}$ Dr hab. Andrzej Kapusta ukończył również lubelską Akademię Medyczną, natomiast doktorat obronił na wydziale filozofii. 
badawcze na wczesny etap twórczości Jaspersa, gdy ten nie zajmował się jeszcze filozofią sensu stricto, ale pracował w klinice psychiatrycznej w Heidelbergu. Te dwie prace zdają się wyznaczać dwa bieguny, pomiędzy którymi można by umieścić inne interpretacje pism niemieckiego filozofa ${ }^{5}$. Bardziej rozległego, choć z konieczności również mniej drobiazgowego, przeglądu problemów, którymi zajmował się Jaspers, dostarczają prace zbiorowe poświęcone jego życiu i twórczości. W 2013 roku ukazała się już druga tego rodzaju publikacja, mianowicie Karl Jaspers: Człowiek w epoce przełomu.

Podobnie jak wydana w 2011 roku Karl Jaspers: Myślenie zaangażowane, również i ta książka jest pokłosiem spotkania największych polskich znawców myśli Jaspersa, skupionych w Polskim Towarzystwie Karla Jaspersa. Jest to jedno z najsprawniej działających stowarzyszeń skupionych nad tak wąskim wycinkiem filozoficznego uniwersum. Mimo względnie niewielkiej liczby członków (zgodnie z danymi zawartymi na stronie www.karljaspers. pl towarzystwo liczy niespełna czterdzieści osób), a dzięki wytrwałej pracy założycielki (Czesławy Piecuch) oraz członków towarzystwa ukazały się w ostatnich trzech latach już dwie książki poświęcone twórczości Jaspersa, a w październiku 2013 roku odbyła się trzecia Ogólnopolska Konferencja Jaspersowska. Artykuły zamieszczone w recenzowanej publikacji są w większości rozszerzonymi wersjami wystąpień wygłoszonych podczas drugiej Konferencji. Odbyła się ona 26 października 2011 roku, a poświęcona była przede wszystkim „duchowej sytuacji epoki”. Tytuł ten daje się odczytywać w dwojaki sposób: z jednej strony jako próba przeanalizowania tez Jaspersa zawartych w Die Geistige Situation der Zeit, pracy, w której analizował on teraźniejszość, ale też możliwą przyszłość człowieka w coraz bardziej technologizującym się świecie; z drugiej można również zadać pytanie o aktualność myśli filozofa dla nas, obywateli świata początków XXI wieku.

Uczestnicy konferencji spełnili obydwa wspomniane zadania, stąd w recenzowanej książce zawarte są zarówno teksty z zakresu historii filozofii, jak i artykuły o charakterze problemowym, próbujące dokonać adaptacji filozofii Jaspersa do wyzwań współczesności. Tom otwiera tekst Iwony Alechnowicz, zatytułowany Program filozoficzny Jaspersa zarysowany w Die geistige Situation der Zeit. Należy pochwalić wybór tekstu, gdyż autorka od wielu lat jest uznaną badaczką dwudziestowiecznej filozofii egzystencji, ze szczególnym

${ }^{5}$ Por. m.in.: M. Żelazny, Filozofia i psychologia egzystencjalna, Wydawnictwo UMK, Toruń 2011, zwł. s. 223-316; R. Król, Geneza człowieka jako jednostki według Karla Jaspersa, Wydawnictwo Heliodor, Warszawa/Łomianki 2012. 
uwzględnieniem Jaspersa ${ }^{6}$, a artykuł jej autorstwa nie tylko traktuje o problemach podjętych przez niemieckiego filozofa w przywołanej pracy, ale stanowi znakomite wprowadzenie do całości jego myśli. Zainteresowanie autorki skupione jest przede wszystkim na stosowanym przez Jaspersa rozróżnieniu na psychologię wyjaśniającą i psychologię rozumiejącą, i jego predylekcji do tej ostatniej, oraz na pojęciu egzystencji ${ }^{7}$. O tym, że jest to jedno z najistotniejszych pojęć filozofii Jaspersa, nie trzeba chyba nikogo przekonywać.

W artykule Nowoczesna sofistyka według Karla Jaspersa Dorota Barcik przechodzi do szczegółowych analiz jednego z pojęć obecnych w Die Geistige Situation. Zwraca uwagę na prawidłowe odczytanie tytułu dzieła Jaspersa, które w żaden sposób nie ma być „teorią współczesności” (co, jak wskazuje autorka, zarzucać miał Jaspersowi Habermas), a pisane jest nadal z perspektywy egzystencjalnej, co w tym kontekście należy rozumieć - ateoretycznej. Jak bowiem nie da się stworzyć „teorii egzystencji”, a można ją co najwyżej rozjaśniać, tak również i sytuacja wymyka się ścisłej analizie. Podążając tropem Jaspera, Dorota Barcik utożsamia współczesną sofistykę z umasowieniem społeczeństwa, zatratą indywidualności tworzących je jednostek, co ma być skutkiem negatywnie rozumianej techniki. Przywołane przez autorkę przykłady zjawisk tego rodzaju z pewnością aktualne są również obecnie, co tylko potwierdza diagnozy Jaspersa (s. 31-32).

W drugiej części tekstu następuje zmiana sposobu narracji, tekst przestaje być analizą koncepcji Karla Jaspersa, a staje się swego rodzaju manifestem,

${ }^{6}$ Patrz zwł. I. Alechnowicz, Karl Jaspers - filozofia i polityka, Wydawnictwo Akademii Rolniczej, Wrocław 1996.

${ }^{7} \mathrm{~W}$ ostatnich latach, zwłaszcza w obszarze anglojęzycznym, można zaobserwować wyraźny wzrost zainteresowania psychologicznym etapem twórczości Jaspersa. Powstaje na ten temat wiele publikacji, co ciekawe - również w czasopismach stricte medycznych. Por. M. Bormuth, Life Conduct in Modern Times. Karl Jaspers and Psychoanalysis, Springer Verlag, Dordrecht 2006; „Psychopathology” 2013, vol. 46: The Centennial of Karl Jaspers' General Psychopathology; P. Fusar-Poli, One Century of 'Allgemeine Psychopathologie' (1913 to 2013) by Karl Jaspers, „Schizophrenia Bulletin”, vol. 39, 2013, no. 2, s. 268-269; S. N. Ghaemi, Existence and Pluralism: the Rediscovery of Karl Jaspers, „Psychopathology” 2007, vol. 40, s. 75-82; tenże, On reading the General Psychopathology: The Importance of Karl Jaspers' Methodological Pluralism for Contemporary Psychiatry, [w:] K. Salamun, G. Walters (red.), Karl Jaspers Philosophy. Expositions \& Interpretations, Humanity Books, New York 2008, s. 37-68. Również planowane na 2014 rok spotkanie Amerykańskiego Towarzystwa Filozoficznego (American Philosophical Association) ma być poświęcone stosunkowi Jaspersa (i przy okazji również Heideggera) wobec osoby i dzieła Van Gogha. Jak wiadomo, niemiecki filozof analizował dzieła wybitnego malarza przede wszystkim z perspektywy psychiatrycznej, por. K. Jaspers, Strindberg i van Gogh, tłum. R. Reszke, Wydawnictwo KR, Warszawa 2006. 
głoszącym konieczność wyzwolenia się z sofistyki. Autorka konstruuje, bądź też cytuje, dialog pomiędzy osobami, którym zgodnie z przyjętymi wcześniej definicjami przypisuje stanowisko sofistyczne oraz wręcz przeciwne. Ta część tekstu wydaje się najsłabsza, gdyż, mimo nadziei autorki, takie postawy, jak bojkot pewnych produktów odzieżowych, nie wystarczą do polepszenia sytuacji ekonomicznej krajów rozwijających się. Razi również pomyłka, która być może jest chochlikiem drukarskim. Otóż mając na myśli, jak mniemam, „fair trade”, czyli ruch mający na celu zwiększenie sprawiedliwości społecznej i walkę z wyzyskiem, posłużyła się sformułowaniem: „Istnieją przecież współczesne mechanizmy obronne przed wyzyskiem, np. trade mark"s (s. 33-34).

Magdalena Derezińska-Osiecka w tekście Światopoglady jako skorupy, w których żyjemy. Jaspersa krytyka racjonalizmu na podstawie psychologii światopogląów porusza inny ważki problem filozofii Jaspersa, mianowicie zagadnienie pułapki racjonalizmu. Problem granic myślenia racjonalnego, logicznego, tego, co rządzi się prawem dnia etc., był dla Jaspersa jednym z kluczowych zagadnień podczas całej jego filozoficznej drogi. $\mathrm{Z}$ pewnością jednak nie twierdził on, że w każdej dziedzinie życia należy się takiego myślenia wystrzegać. Filozof niejednokrotnie powtarzał, że dopiero wysoki poziom biegłości w jakiejś dziedzinie przedmiotowej stanowi swego rodzaju uzasadnienie dla zajmowania się filozofią. Zanim zdecydujemy się na transcendujące myślenie o całości, powinniśmy odkryć (a nie tylko apriorycznie założyć i na tej podstawie porzucić racjonalne badanie świata) granice rozumu i zdać sobie sprawę z niemożliwości całościowego poznania choćby jednego wycinka rzeczywistości ${ }^{9}$. Być może autorka jest świadoma powyższego faktu, jednak z jej tekstu można wysnuć wniosek, jakoby Jaspers w ogóle odżegnywał się od poznania racjonalnego, a postulował skierowanie się ku jakiejś formie mistyki. Użycie określenia „mistyka” w odniesieniu do filozofa, który wyraźnie potwierdzał, niemal przez całą Wiarę filozoficzna wo-

${ }^{8}$ Trade mark (ang.), czyli znak towarowy. Istnienie znaków towarowych, czyli popularnych marek, na przykład odzieżowych, zgodnie z logiką tekstu byłoby raczej czynnikiem pogarszającym sytuację wspomnianych w artykule robotników w krajach tzw. Trzeciego Świata.

${ }_{9}^{9}$ Mogłaby to potwierdzać jego własna biografia. Gerhard Knauss sugeruje wręcz, że na mocy przyjętych przez Jaspersa założeń w ogóle nie powinno być kogoś takiego, jak „zawodowi filozofowie”, a filozofowanie powinno stać się udziałem ludzi zajmujących się „twardą” nauką, por. G. Knauss, Karl Jaspers on Philosophy and Science, [w:] K. Salamun, G. Walters (red.), Karl Jaspers's Philosophy. Expositions \& Interpretations, s. 73-74. Ta teza wydaje się jednak zbyt daleko idąca. 
bec objawienia, niemożliwość jakiegokolwiek, a więc również mistycznego, bezpośredniego kontaktu $\mathrm{z}$ transcendencją, jest wysoce problematyczne. Egzystencjalne transcendowanie jest raczej, jeśli w ogóle moglibyśmy posłużyć się wyrażeniem przestrzennym, „transcendowaniem do wewnątrz”. $\mathrm{Z}$ drugiej strony, być może autorka posługuje się innym niż potoczne rozumieniem słowa „mistyczny”. Nie sposób jednak tego stwierdzić, gdyż ten wątek nie został rozwinięty. Powyższy tekst jest bardzo inspirujący i składania do refleksji oraz polemiki, zwłaszcza że ze względu na jego niewielką objętość wiele kwestii domagałoby się uzupełnienia i dopowiedzenia.

Podobny zarzut można podnieść w stosunku do artykułu Antoniny Sebesty: Karla Jaspersa diagnoza i terapia demokracji. Dokonuje ona trafnej rekonstrukcji tekstu Jaspersa poświęconego wyzwaniom, przed którymi stoi współczesna praktyka polityczna, jednak jest to analiza tekstu bądź co bądź popularyzatorskiego ${ }^{10}$. Taki wybór materiału do opracowania może dziwić, gdyż autorka doskonale zdaje sobie sprawę z mnogości publikacji dotyczących polityki, które wyszły spod pióra niemieckiego filozofa (s. 45). Nie da się jednak ukryć, że przywołana przez nią diagnoza klasy politycznej w RFN $\mathrm{w}$ latach 60. ubiegłego stulecia, pozostaje niepokojąco aktualna również obecnie w naszym kraju.

Nie sposób również odmówić refleksjom Jaspersa aktualności, gdy pisze on o stopniowym wypaczaniu idei uniwersytetu. Paweł Wójs (Karla Jaspersa idea uniwersytetu i uniwersytet realny) dokonał wyśmienitej analizy poglądów niemieckiego filozofa w kwestii wspólnego poszukiwania prawdy przez całą uniwersytecką wspólnotę oraz wskazał przykłady zbaczania z tej drogi. Tekst wzbogacony został nawiązaniami do poglądów Johna Henry’ego Newmana oraz kilku polskich filozofów, ze szczególnym uwzględnieniem Władysława Stróżewskiego, dzięki czemu możemy przekonać się, że sentyment wobec pewnego klasycznego uniwersyteckiego ethosu charakteryzował nie tylko Jaspersa, ale wspólny bywa wielu spośród tych, którzy właśnie uniwersytetowi poświęcili swe życie. Są to kwestie, które nie dają o sobie zapomnieć, gdyż stoimy właśnie przed pytaniem o przyszłość filozofii uniwersyteckiej. Jak się wydaje, odpowiedź udzielana przez środki masowego przekazu oraz przedstawicieli władzy odbiegają nieco od postulatów Humboldta (por. s. 55). Pozostaje mieć nadzieję, że idea poznania służącego poznaniu (i niczemu więcej) obroni się sama, gdyż w świecie XXI wieku orędowników ma

${ }^{10}$ Taki bowiem charakter ma wydana w latach 60. książeczka Kleine Schule des philosophischen Denkens. 
coraz mniej. W ten sposób wracamy do jednej z podstawowych tez Duchowej sytuacji epoki, mianowicie prymatu technologii, praktyczności i wydajności.

Wszystkie trzy utrudniają (a przynajmniej - nie ułatwiają) komunikację, jeśli będziemy rozumieć ją w sposób egzystencjalny, czyli dla Jaspersa kluczowy. Podejmujący to zagadnienie Maciej Urbanek ${ }^{11}$ posuwa się jednak za daleko w swej krytyce, której adresatem czyni między innymi media. Owszem, trudno w relacji nadawca-komunikat-odbiorca dopatrzeć się znamion ujawniania egzystencji, jednak nie to jest przecież jej celem. Komunikacja egzystencjalna zachodzi bowiem tylko pomiędzy dwoma otwartymi na siebie egzystencjami, a wymaganie jej na przykład od telewizji jest przesadą. Tego rodzaju komunikaty są bowiem wymianą informacji ${ }^{12}$ pomiędzy „świadomościami w ogóle" i jako takie z definicji bywają odpersonalizowane. Chodzi w nich bowiem o prawdę obiektywną, a nie o prawdę egzystencjalną, do uzyskania tej pierwszej zaś nie jest potrzebne zaangażowanie, otwartość na egzystencję etc., a raczej rzetelność, logiczność i jasność przekazu. To przeoczenie ze strony autora jest zaskakujące, gdyż kilka stron wcześniej cytuje on Jaspersowskie rozróżnienie na poszczególne odmiany komunikacji, więc nie powinien mieć trudności z zastosowaniem ich w praktyce.

Nie sposób zatem zgodzić się ze stwierdzeniem: „komunikacja, jaką opisuje Jaspers, jest czymś zupełnie innym niż ta, którą mamy obecnie" (s. 85). Jeśli będziemy miarę komunikacji egzystencjalnej przykładać na przykład do przekazu medialnego, to niewątpliwie czeka nas rozczarowanie, jednak z pewnością nie takie były intencje niemieckiego filozofa. Z drugiej strony, ponieważ autentyczna egzystencjalna komunikacja jest czymś wymykającym się racjonalnemu dowodzeniu i wszelkiej tematyzacji, to można tylko, wzorem Jaspersa, apelować do autora, by się na nią otworzył, bo z pewnością wciąż jest jeszcze dla niego możliwa. Nasze czasy nie są bowiem ani lepsze ani gorsze jeśli chodzi o możliwość zawarcia autentycznej przyjaźni czy odczucia prawdziwej miłości, a chyba właśnie to miał na myśli autor Die geistige Situation der Zeit.

Równie specyficznie zrozumiał intencje Jaspersa autor artykułu zamykającego pierwszą część niniejszej książki. W tekście Wokół transcendencji. Karl Jaspers w sporze z chrześcijaństwem Antoni Szwed za słabość filozofii Jaspersa uznał to, co sam filozof cenił w niej najbardziej. Autor ubolewa nad niemoż-

\footnotetext{
${ }^{11}$ Artykuł: Fenomen komunikacji a sytuacja duchowa epoki.

${ }^{12}$ Nie mogę zgodzić się z autorem, gdy twierdzi on, że odbiorca jest stroną całkowicie bierną $\mathrm{w}$ tym procesie, jednak to zagadnienie zdecydowanie wykracza poza zakres niniejszej recenzji.
} 
liwością jakiegokolwiek pojęciowego wyrażenia transcendencji (z jakiegoś powodu pisząc to słowo wielką literą), nie dostrzegając, że takowe wyrażenie odebrałoby jej całą moc, umożliwiającą rozjaśnianie egzystencji. Co więcej, Antoni Szwed bardzo chciałby uczynić Jaspersa filozofem chrześcijańskim, by móc następnie wykazać błędy jego rozumienia tej „chrześcijańskości”. Jest to jednak zabieg chybiony, gdyż Jaspers filozofem chrześcijańskim nie jest, i to pomimo tego, że na przykład Jean-Paul Sartre już w latach 60. pisał: „myśl Jaspersa jest teologią, która nie ma odwagi się do tego przyznać" ${ }^{13}$. Chrześcijańskim filozofem nie czyni Jaspersa nawet fakt, że właśnie biblijne szyfry analizował najdokładniej i najszerzej komentował. Bliżej prawdy byłby zatem Mounier: „Taki Jaspers, który podniósł niedokończenie do rangi kryterium ludzkiego istnienia, nie może nawet być nazwany filozofem chrześcijańskim, choć wszystkie drgnienia jego myśli, z wyjątkiem może ostatniego, dokonują się w samym miąższu chrześcijaństwa ${ }^{14 "}$; jednak również i on, podobnie jak jego wybitny rodak Gabriel Marcel nie potrafił się chyba pogodzić z faktem, że choć Jaspers niewątpliwie inspirował się Pismem Świętym, to nigdy nie poddał się jego autorytetowi ${ }^{15}$.

W myśl interpretacji zaprezentowanej w odnośnym artykule Jaspers miałby „ukrywać" chrześcijańskiego Boga pod wieloznacznym pojęciem transcendencji i zaciemniać przekaz religijny pod przykrywką jakichś „szyfrów”. Tymczasem autor nie akceptuje faktu, że w filozofii Jaspersa samo chrześcijaństwo, wraz ze wszystkimi swymi symbolami, naukami i przekazami jest właśnie szyfrem. Szyfrem, który nie odsyła, jak chciałby to widzieć Szwed, do jakiegoś zjawiska innego rodzaju, ale do tej części ludzkiego „ja”, która jest wolnością. Przyjęcie „immanentnej transcendencji” może oczywiście niepokoić badacza reprezentującego światopogląd chrześcijański (bo Bóg znany z Pisma Świętego mógłby w efekcie okazać się zbędny i zastępowalny jakimś innym szyfrem), jednak w sensie poznawczym nie jest to hipoteza mniej sensowna niż to, czego nauczają religie. Do istoty transcendencji przynależy bowiem to, że samo udowadnianie czym ona jest bądź nie jest, jest sprzecznością i jeśli przemawia do egzystencji, to w tym sensie wystarczy do

\footnotetext{
${ }^{13}$ J.-P. Sartre, List: Marksizm a filozofia egzystencji, [w:] R. Garaudy, Perspektywy człowieka, tłum. Z. Butkiewicz, J. Rogoziński, Książka i Wiedza, Warszawa 1968, s. 124.

${ }^{14}$ E. Mounier, Wprowadzenie do egzystencjalizmów, [w:] Wprowadzenie do egzystencjalizmów oraz wybór innych prac, tłum. J. Zabłocki, Znak, Kraków 1964, s. 222.

${ }^{15}$ Por. G. Marcel, Sytuacja podstawowa i sytuacje graniczne u Karla Jaspersa, [w:] tenże, Od sprzeciwu do wezwania, tłum. S. Ławicki, Instytut Wydawniczy PAX, Warszawa 1965.
} 
jej prawdziwości. Innymi słowy, zarzut subiektywizmu nie jest zarzutem dotykającym sedna Jaspersowskiej koncepcji szyfrów transcendencji.

Artykuły zamieszczone w drugiej części książki Karl Jaspers: człowiek $w$ epoce przełomu są próbami porównania Jaspersowskiej diagnozy epoki z refleksjami innych badaczy. Część tę otwiera Romuald Piekarski tekstem poświęconym Jaspersowi i Voegelinowi. Jest to bodaj pierwsza w polskim piśmiennictwie próba zestawienia właśnie tych dwu myślicieli, a zarazem jeden $\mathrm{z}$ najdłuższych tekstów zamieszczonych w niniejszym tomie. Ze względu na nowatorskość ujęcia tematu oraz dość szczegółowe jego opracowanie artykuł ten z pewnością zasługuje, by się z nim dokładnie zapoznać (i to pomimo, że autor z przesadną skromnością pisał o jego powierzchowności etc., s. 126). Chociaż Jaspers nie był filozofem polityki w klasycznym rozumieniu tego słowa, to wyprowadzone przez niego wnioski dotyczące źródeł totalitaryzmu i wskazówki, jak należy się w jego obliczu zachować, okazywały się zaskakująco zgodne z przemyśleniami bardziej doświadczonego w tej materii Voegelina.

W kolejnym, nieco publicystycznym artykule Kryzys „europejskiego człowieczeństwa" Tadeusz Gadacz pisze o kryzysie ducha, który zaobserwować można w naszym obszarze kulturowym. W przeciwieństwie do pozostałych, ów tekst nie jest przedrukiem referatu wygłoszonego podczas II Ogólnopolskiej Konferencji Jaspersowskiej; Gadacz opublikował go wcześniej w czasopiśmie „Charaktery”. Jest to miesięcznik „z założenia popularyzujący wiedzę psychologiczną w sposób zrozumiały dla przeciętnego człowieka"16 - i mniej więcej taką specyfikę posiada ów esej. Jaspers "tonie” w zalewie nazwisk, spośród których można wymienić między innymi: Diltheya, Husserla, Horkheimera, Gadamera Bubera i Marquarda (a wszystko to na niespełna dziesięciu stronach) i jest raczej „przywołany” niż „przeanalizowany”, czy choćby „porównany" $\mathrm{z}$ innymi. Wielkiej erudycji autora zawdzięczamy natomiast to, że tekst czyta się z przyjemnością i z pewnością jego lektura może być chwilą wytchnienia po zmaganiach $\mathrm{z}$,twardymi” filozoficznymi analizami.

Specyficzny, choć pod innym względem, jest również artykuł Janusza Krupińskiego Homo schistos: soba (nie) bycie. Tekst przepełniony jest dygresjami, wtrąceniami i lakonicznymi zapytaniami autora, argumentacja prowadzona jest bardzo dynamicznie, mnogość podjętych wątków robi wrażenie,

${ }^{16}$ Określenie zaczerpnięte z opisu na portalu wikipedia.pl. Owo stwierdzenie nie jest żadnym definitywnym określeniem, tym niemniej trafnie oddaje charakter (nomen omen) owego pisma. 
zwłaszcza, że udało się przy tym nie zatracić spójności i przejrzystości tekstu. Krupiński z pewnością wykazuje większy niż pozostali autorzy krytycyzm w stosunku do filozofii Jaspersa i jej podstawowych pojęć, takich jak m.in. bycie sobą czy egzystowanie (ostrze tej krytyki wymierzone jest nawet silniej w pewne sposoby odczytywania tych kategorii u niektórych badaczy Jaspersa, niż w samego filozofa), dzięki czemu jego esej (notabene zdecydowanie wykraczający objętościowo poza inne zawarte w tomie) może być w pewnym sensie „powiewem świeżości” dla badaczy wrośniętych w Jaspersowską terminologię i w pełni ją aprobujących.

Badaczom Jaspersa dobrze znana jest waga, jaką przypisywał on wolności. $\mathrm{W}$ wielu interpretacjach to właśnie wolność jest kluczowym pojęciem jego filozofii, dlatego bardzo interesujące są badania Moniki Mazur-Bubak. W artykule Karla Jaspersa krytyka liberalnej koncepcji wolności prezentuje ona krytykę, którą autor Die Geistige... wymierzył w odmienną od własnej koncepcję wolności ${ }^{17}$, przy czym, zdaniem autorki, niezgoda Jaspersa dotyczyć miała przede wszystkim „całkowitej niezależności człowieka od innych” (s. 185). Nie wiem, na ile w liberalizmie Locke’a, do którego przede wszystkim odnosi się autorka tekstu, autonomia jednostki rzeczywiście ma sięgać tak daleko, że zbędna staje się komunikacja $\mathrm{z}$ innymi, tym niemniej Monika Mazur-Bubak ma niewątpliwie rację, twierdząc, że $\mathrm{w}$ myśli Jaspersa byłoby to niedopuszczalne. Z pewnością filozofia polityczna Jaspersa byłaby pewną formą liberalizmu, aczkolwiek z powodu niejednoznaczności pojęcia „liberalny” we współczesnym dyskursie, należałoby podkreślić, że jest to nieco inny rodzaj liberalizmu niż Locke’owski.

Jaspersowska koncepcja wolności wiele zawdzięcza doktrynie Immanuela Kanta. Stosunek autora Philosophie do filozofa z Królewca stał się przedmiotem analiz Jakuba Szczepańskiego, który w tekście Karl Jaspers -jedyny uczeń $K$ anta $^{18}$ skupił się wyłącznie na myśli politycznej obydwu, dzięki czemu jego artykuł może korespondować z uprzednio omówionym tekstem Moniki Mazur-Bubak. Autor zastanawia się, na ile w ogóle można mówić o Kanta filozofii polityki, a nie tylko o publicystyce politycznej, a także stawia oryginalną tezę o istnieniu „szkoły Jaspersa”, do której, poza samym założycielem, mieli należeć jeszcze Arendt i Hans Saner. Zabrakło, niestety, pogłębionej anali-

\footnotetext{
${ }^{17}$ Autorka opracowuje przede wszystkim $O$ źródle i celu historii, czyli największe spośród przełożonych na język polski dzieło Jaspera, poświęcone po części kwestiom relacji międzyludzkich w aspekcie powszechnym (innymi słowy - polityce).

${ }^{18}$ Nie jest to prowokacja ze strony autora, a parafraza słów Hannah Arendt.
} 
zy obydwu koncepcji, tym niemniej, dzięki wskazówkom bibliograficznym zawartym w przypisach, czytelnik może z łatwością dokonać jej na własną rękę ${ }^{19}$.

Zupełnie nowatorskie są badania nad wpływem, jaki Jaspers mógł wywrzeć na polskiego twórcę Mieczysława Jastruna (artykuł Marcina Urbaniaka Jaspersowskie inspiracje myśli egzystencjalnej Mieczysława Jastruna). Szukanie filozoficznych inspiracji u poetów bywa nieraz obarczone ryzykiem nadinterpretacji, jednak w tym przypadku wydaje się uzasadnione, gdyż, jak wskazuje Urbaniak, sam Jastrun wielokrotnie wspomina o Jaspersie w swych notatkach i dziennikach (s. 196). Badania Urbaniaka dowodzą, że mimo odmiennego aparatu pojęciowego i horyzontu myślowego, pewne głębokie egzystencjalne poruszenie i troska były wspólne obydwu myślicielom. Dowodzi to, nie pierwszy zresztą raz w niniejszym tomie, uniwersalności diagnoz postawionych przez Jaspersa.

Ostatnim tekstem zawartym w tomie Karl Jaspers: człowiek $w$ epoce przełomu, a zarazem podsumowaniem jego treści, jest artykuł Czesławy Piecuch Czas przełomu: Koniec czy poczatek człowieka? Jaspers i Fukuyama. Owo podsumowanie może napawać optymizmem, ukazuje bowiem, że choć diagnoza zaprezentowana przez Jaspersa w Die geistige Situation der Zeit nie jest zbyt pokrzepiająca, to sam filozof ukazywał możliwości wyjścia z duchowego kryzysu. Wypracowanie autentycznej ludzkiej wspólnoty, która zastąpi masę sterowaną przez wyalienowaną klasę polityczną i korporacje biznesowe, jest jedyną drogą, na której możemy odzyskać swą indywidualność. Jaspers widział zatem sytuację współczesnego sobie człowieka w nieco jaśniejszych barwach niż podejmujący niemal te same zagadnienia osiem dekad później Francis Fukuyama. Ten ostatni, jak dowodzi Czesława Piecuch, zatracił już chyba wiarę w człowieka i jego los. Chociaż od publikacji dzieła Jaspersa upłynęło niemal osiemdziesiąt lat, opisywany zaś przez niego jako szansa, a zarazem zagrożenie postęp technologiczny nabrał tempa, o którym filozofowi z pewnością nawet się nie śniło, to nauka płynąca $\mathrm{z}$ jego dzieła może przemawiać dziś do nas równie mocno co w 1931 roku (a może nawet bardziej, zważywszy, że mamy za sobą okrucieństwo II wojny światowej, którą Jaspers mógł co najwyżej antycypować). Sami musimy dokonać wyboru, czy zgodzimy się z Jaspersem, że „człowiek wciąż jest na rozdrożach”, czy z Fukuyamą, zdaniem którego „można tylko zastanawiać się, czy człowiek zboczy z drogi prowadzącej go ku przepaści” (s. 223).

\footnotetext{
${ }^{19}$ Kluczowa będzie tu praca Iwony Alechnowicz, por. przyp. 7.
} 
Artykuł Czesławy Piecuch, wraz z otwierającym tom esejem Iwony Alechnowicz, stanowią klamrę spajającą książkę w jedną całość. Mnogość perspektyw, z których ujmuje się jakieś zagadnienie, powoduje czasem wrażenie chaosu, jednak w przypadku recenzowanej książki działa zdecydowanie na korzyść. Jaspers okazuje się bowiem myślicielem wielowymiarowym, możliwym do odczytania na różne sposoby, które dają się ze sobą konfrontować, oczywiście zgodnie z jego własnym postulatem, na drodze „miłosnej walki o prawdę”, a nie „walki o zwycięstwo”. Niniejsza publikacja pozwala czytelnikowi odkryć mniej znane oblicze niemieckiego filozofa. Dotychczasowe monografie ukazywały go raczej jako abstrakcyjnego uczonego, którego specyficzny i hermetyczny aparat pojęciowy bywał barierą utrudniającą nawiązanie z jego zwolennikami autentycznego dialogu. W Karl Jaspers: człowiek w epoce przełomu ukazał się natomiast jako zatroskany o los ludzkości myśliciel, który podaje jak najbardziej praktyczne i konkretne drogi wyjścia z duchowego kryzysu. Zawarte w książce teksty są zróżnicowane pod względem objętości, sposobu ujęcia i zakresu tematycznego, wszystkie jednak prezentują poziom zachęcający do ich lektury, nawet jeśli w niektórych przypadkach lektury tylko po to, by potem z nimi polemizować.

Dawid Kolasa 